Artvin Çoruh Üniversitesi

Orman Fakültesi Dergisi

ISSN:2146-1880, e-ISSN: 2146-698X

Yıl: 2018, Cilt: 19, Sayı:1, Sayfa: 18-26

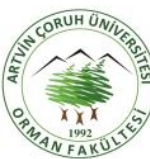

ofd.artvin.edu.tr

(c) (i)
Artvin Coruh University

Journal of Forestry Faculty

ISSN:2146-1880, e-ISSN: 2146-698X

Year: 2018, Vol: 19, Issue: 1, Pages: 18-26

\title{
Türkiye'de oduna dayalı orman ürünleri üzerine bir araştırma: Zaman serisi analizi
}

\author{
A research on wood based forest products in Turkey: Time series analysis
}

Mahmut Muhammet BAYRAMOĞLU

Karadeniz Teknik Üniversitesi, Orman Fakültesi, Orman Mühendisliği Bölümü, Trabzon, Türkiye

Eser Bilgisi / Article Info

Araştırma makalesi / Research article

DOI: 10.17474/artvinofd.333344

Sorumlu yazar / Corresponding author Mahmut Muhammet BAYRAMOĞLU

e-mail: mahumd@ktu.edu.tr

ORCID: 0000-0002-0870-5094

Geliş tarihi / Received

07.08.2017

Düzeltme tarihi / Received in revised form

17.11.2017

Elektronik erişim / Online available

08.12.2017

\section{Anahtar kelimeler:}

Durağanlık

Endüstriyel odun

Ormancilık

Keywords:

Stationarity

Industrial wood

Forestry

\begin{abstract}
Özet
Gelişen teknoloji her türlü odun ürününe olan talebi arttırmıştır. Bu durum sahip olunan kaynakların sürdürülebilir kullanımının yanında etkin ve verimli kullanılmaları sonucunu da beraberinde getirmiştir. Zaman serileri analizi de mevcut değişkenlerin gelecekte alabilecekleri değerleri kestirimine imkân verdiği için odun hammaddesini olan ormanların planlanmasında önemli bir araç olarak kullanılmaktadır. Orman Genel Müdürlüğü ormanların işletilmesinden sorumlu kamu kurumu olarak satış stratejilerini ve gelirlerini bu planlara göre düzenlemek durumundadır. Bu kapsamda çalışmada 2001-2016 yılı endüstriyel odun, dikili ve yakacak odun satış ve gelir verilerinden oluşturulan modellerle 2017-2027 yılına ait satış ve gelir tahminlerinde bulunulmuştur. Çalışma sonucunda endüstriyel odun ve dikili satış miktarlarında sırasıyla 2027 yılı sonu için 4.96 milyon $\mathrm{m}^{3}$ ve 564 bin $\mathrm{m}^{3}$ artış, yakacak odun gelirlerinde ise 1.11 milyon ster azalışa rağmen gelirlerde 84.9 milyon TL artış beklenmektedir. Geleceğe yönelik yaşanacak politik ve ekonomik sonuçlara göre bu tahminler değişim gösterecektir. Ancak yine de karar vericilerin sayısı az olmasına rağmen bu tarz çalışmalardan elde edilen çıktıları göz önünde bulundurarak planlarını oluşturmaları başta ormancılık olmak üzere Türkiye ekonomisi açısından önem arz etmektedir.
\end{abstract}

\begin{abstract}
The developing technology has increased the demand for all kinds of wood products. This has resulted in the use of efficient and productive use of resources as well as sustainable use. Time series analysis is also used as an important tool in the planning of forests with wood raw materials because it allows to estimate the future values of existing variables. The General Directorate of Forestry has to organize sales strategies and incomes according to these plans as the public institution responsible for the management of forests. In this context, sales and income forecasts for the year 2017-2027 were made for models produced from sales of industrial wood, stumpage and fuelwood and income data for the year 2001-2016. As a result of the study, it is expected that the sales of industrial wood and stumpage will increase by 4.96 million $\mathrm{m}^{3}$ and 564 thousand $\mathrm{m}^{3}$ for the end of 2027 respectively, while the fuelwood income decreases by 1.11 million stere. These estimates will change according to the political and economic consequences for the future. Nevertheless, it is important for decision-makers to formulate their plans in view of forestry and Turkish economy, especially in view of the outputs from such studies, although the number is inadequate.
\end{abstract}

\section{Giriş}

İs hayatındaki ve piyasalardaki uzun vadeli belirsizlikler günümüzde gerek özel gerekse kamu sektörü işletmelerinin geleceklerini şekillendiren hayati kararları almasını güçleştirmektedir. Bununla birlikte sürekli ve hızlı değişim gösteren çevre koşulları da işletmelere bu değişime ayak uydurma zorunluluğu getirmektedir. İşletmeler böyle bir ortamda hem çevre değişimlerini tahmin etmek, hem belirsizliğin sebep olduğu karmaşıklığı çözmek, hem de rekabet üstünlüğü sağlamak zorundadırlar (Langford and Male 2001). Özellikle kamu işletmeleri, topluma en iyi hizmeti en verimli ve etkin şekilde sunacak strateji ve yöntemlerinin geliştirilmesini amaçlamaktadırlar. Bu da ancak çok hızlı değişen dünyada bu değişimlere karşı kamu örgütlerinin ayak uydurabilmesi için uzun dönemli vizyona sahip olmaları ve bu uzun dönemli perspektif ile gerekli stratejilerin belirlenerek uygulamaya konmasıyla mümkündür (Nut and Backoff 1992; Pamuk ve ark. 1997). İşletmeler, hedeflerini belirlemelerinin yanında bu hedeflere ulaşabilmek için uygulamaları gereken stratejiler için de iktisadi ölçümlerden yararlanmak zorundadırlar. İktisadi ölçüm için yapılan analizlerde kesit veri, zaman serileri ve panel veri olmak üzere üç türlü veri kullanılmaktadır (Zeren 2010). Zaman serisi, ilgilenilen bir büyüklüğün zaman içerisinde sıralanmış ölçümlerinin bir kümesi olarak tanımlanmaktadır. Zaman serisi ile ilgili analizlerin 
yapılma amacı, gözlem kümesince temsil edilen gerçeğin anlaşılması ve zaman serisindeki değişkenlerin gelecekteki değerlerinin doğru bir şekilde tahmin edilmesidir (Allen 1964). Bu nedenle zaman serileri diğer veri setlerine göre daha çok tercih edilmektedirler.

Türkiye'de ormanların işletilmesinden sorumlu tek kurum Orman ve Su İşleri Bakanlığı bünyesinde faaliyet gösteren Orman Genel Müdürlüğü (OGM)'dür. OGM aynı zamanda oduna dayalı orman ürünü üretiminde ve satışında da Türkiye'nin en büyük tedarikçisi durumundadır. OGM'nin oduna dayalı orman ürünleri, endüstriyel odun (tomruk, tel direk, maden direk, sanayi odunu, kağıtlık odun, lif yonga odunu ve sırık), yakacak odun ve 1997 yılından itibaren uygulamaya başlanan dikili damgadır. 2016 yılı aralık ayı sonu itibariyle $\mathrm{OGM}, 13.7$ milyon $\mathrm{m}^{3}$ endüstriyel odun satışından 2.2 milyar TL, 4.63 milyon $\mathrm{m}^{3}$ dikili satışından 472.4 milyon TL ve 2.5 milyon ster yakacak odundan 115.8 milyon TL olmak üzere toplam 2.78 milyar TL gelir elde etmiştir. OGM gerek sahip olduğu fiziki imkanları ve insan kaynağılla gerekse ülke ekonomisine sağladığı katma değer miktarıyla Türkiye'nin en önemli kamu kurumlarından bir tanesidir. Bu nedenle OGM'nin değişen pazar şartlarına ayak uydurabilmesinin yanında sahip olduğu kaynakları daha etkin ve verimli kullanabilmesi için geçmiş verilerinden yararlanarak geleceğe yönelik tahminler içeren stratejiler oluşturması oldukça önemlidir.

Bu çalışma ile OGM'nin 2001-2016 yılları oduna dayalı orman ürünleri satış miktarlarıyla elde ettikleri satış gelirleri zaman serisi analiziyle değerlendirilerek 20172027 yıllarını kapsayan satış miktarı ve gelir değerleri tahmin edilmiştir. Bu değerlerden yola çıkarak Türkiye ormancılığı ve özellikle 2023 yılına ilişkin temel hedeflere ulaşılması noktasında öneriler geliştirilmiştir.

\section{MATERYAL ve YÖNTEM}

Çalışmada 2001-2016 dönemi oduna dayalı orman ürünleri satış miktarları ve gelirlerine ilişkin veriler kullanılmıştır. Odun ürünleri; endüstriyel odun, dikili ve yakacak odun şeklinde 3 grup altında sınıflandırımıştır.

Çalışmada tek değişkenli zaman serisi kullanılmıştır. Zaman serileri; zaman birimleri saat, gün, ay, yıl gibi değişkenlerin aldığı değerlerin değişimini göstermektedir. Bu kapsamda her bir ürün grubuna ait satış miktarları ve gelirleri 3'er aylık dönemler şeklinde hesaplanmıştır.

Zaman serileri, özelliği ve yapısı ile bizzat kendisi geleceğin tahmininde kullanılan bir bilgi kaynağı olduğu gibi, aynı zamanda bir yöntem olmaktadır. Zaman serisinde verilerden anlamlı ilişkiler elde edilebilmesi için serilerin durağan seriler olması gerekmektedir. Bu nedenle, analizin (regresyonun) gerçek bir ilişkiyi mi, yoksa yanıltıcı bir ilişkiyi mi ifade ettiği, zaman serisi verilerinin durağan olup olmamalarıyla ilgilidir (Tarı, 2014).

Değişkenlerin zaman içinde belli bir değere doğru yaklaşımları olarak tanımlanan durağanlığın belirlenmesinde çeşitli yöntemler kullanılmaktadır. Çalışmada ürün grupları veri setlerinin durağanlıkları Dickey Fuller testi (ADF) birim kök sınaması ile test edilmiştir. ADF testi için önerilen regresyon modelleri ;

$$
\begin{aligned}
& Y_{t}=\delta Y_{t-1}+\sum^{m} \beta_{i} \Delta Y_{t-i}+1+\varepsilon_{t} \\
& Y_{t}=a_{0}+\delta Y_{t-1}+\sum^{m} \beta_{i} \Delta Y_{t-i}+1+\varepsilon_{t} \\
& Y_{t}=a_{0}+\delta Y_{t-1}+\beta_{t}+\sum^{m} \beta_{i} \Delta Y_{t-i}+1+\varepsilon_{t}(3)
\end{aligned}
$$

ADF testi için kullanılan modellerde $Y$ durağanlığı belirlenmek istenen değişkeni, $t$ zamanı, $\Delta$ fark parametresini $\alpha, \delta$ ve $\beta$ sabit katsayıları, m gecikme sayısını, $\varepsilon_{\mathrm{t}}$ en küçük kareler varsayımlarına uyan tesadüfü hata terimlerini göstermektedir. Modellerde (1) numaralı denklem sabitsiz ve trendsiz modeli, (2) numaralı denklem sabitli modeli ve (3) numaralı denklem de sabitli ve trendli modeli göstermektedir.

Serilerin durağanlık testi için ADF testinde sabit terimsiz, sabitli ve trendli (eğilimli) bir süreç izlenir. Buna göre seri eğilimli bir süreçte durağan hale gelmişse, diğer süreçler izlenmeksizin bu değer esas alınır. Seri durağan hale gelmemişse, sabit terimli, bunda da durağanlık sağlanamamışsa, sabit terimsiz sınama yapılır ve bu süreç sonucunda seriyi durağan hale getiren değer baz alınır (Enders 2014).

ADF ile elde edilen sonuçlar $\% 1, \% 5$ ve $\% 10$ anlamlılık düzeyinde MacKinnon kritik değerleriyle karşılaştırılabilir. 
Eğer ADF testi $t$ istatistiği MacKinnon kritik değerinden mutlak olarak büyük değilse, seri durağan değildir ve durağanlığı sağlanıncaya kadar farkının alınması gerekmektedir (Beşkaya ve Manan 2009).

Söz konusu serilerde mevsimselliğin etkisi önemli görüldüğünden, mevsimsel olarak düzeltilmişlerdir ve 2017 - 2027 yıllarını kapsayan satış ve gelir değerlerinin tahmini için aşağıdaki model oluşturulmuştur;

$Y_{t}=a+b X_{t}+\varepsilon_{t}$

Modelde $Y_{t}$ tahmini satış ve gelir değerlerini, $X_{t}$ satış/gelir miktarını, $t$ zamanı ve $\varepsilon_{t}$ ise hata terimlerini ifade etmektedir.

Oluşturulan şekiller yardımıyla 2017 - 2027 yılları için elde edilen değerler ile geçmiş yılların değerleri karşılaştırılmıştır.

\section{BULGULAR}

Çalışmada 2001-2016 yılları endüstriyel odun, dikili ve yakacak odun ürün gruplarının satış ve gelir değerleri 3'er aylık dönemler (Quarter - Q) şeklinde düzenlenmiştir. Böylece zaman serimiz 2001:Q1'den başlayarak 2016:Q4'te bitmektedir. Çizelge1.'de endüstriyel odun, dikili ve yakacak oduna ait ortalama ve standart sapmaları verilmiştir. Çizelge 1 . incelendiğinde standart sapmaların oldukça yüksek olduğu görülmektedir. Bu durum 20012016 yılları ürün gruplarının satış ve gelir rakamlarının değişkenliğinin de yüksek olduğunun bir göstergesidir.

Endüstriyel odun satış miktarı (ENDSAT), endüstriyel odun geliri (ENDGEL), dikili satış miktarı (DIKSAT), dikili satış geliri (DIKGEL), yakacak odun satış miktarı (YAKSAT) ve yakacak odun geliri (YAKGEL) Şekil 1 - 3'te görülmektedir.

Çizelge 1 Ürün gruplarına ait ortalama ve standart sapma değerleri

\begin{tabular}{|c|c|c|c|c|c|c|}
\hline & Endüstriyel Odun & & Dikili & & Yakacak Odun & \\
\hline & Satış Miktarı $\left(.000 / \mathrm{m}^{3}\right)$ & Gelir (.000/TL) & Satış Miktarı $\left(.000 / \mathrm{m}^{3}\right)$ & Gelir (.000/TL) & Satış Miktarı $\left(.000 / \mathrm{m}^{3}\right)$ & Gelir (.000/TL) \\
\hline Ortalama & 2473.78 & 287999.4 & 527.50 & 49942.78 & 1081.69 & 24157.28 \\
\hline Standart Sapma & 768.79 & 155582.3 & 495 & 57269.89 & 899.15 & 12722.48 \\
\hline
\end{tabular}

ENDSAT

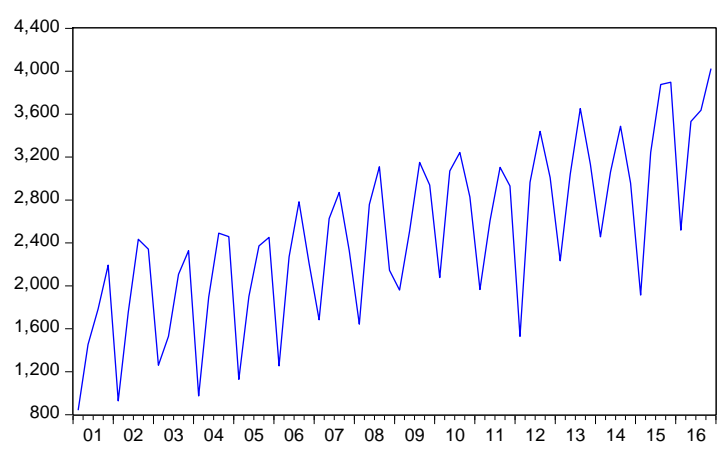

ENDGEL

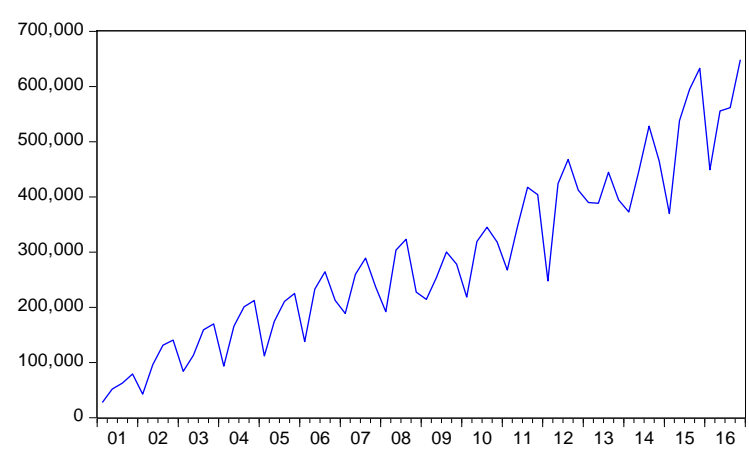

Şekil 1 2001-2016 yılları endüstriyel odun satış miktarı ve gelirleri

DIKSAT

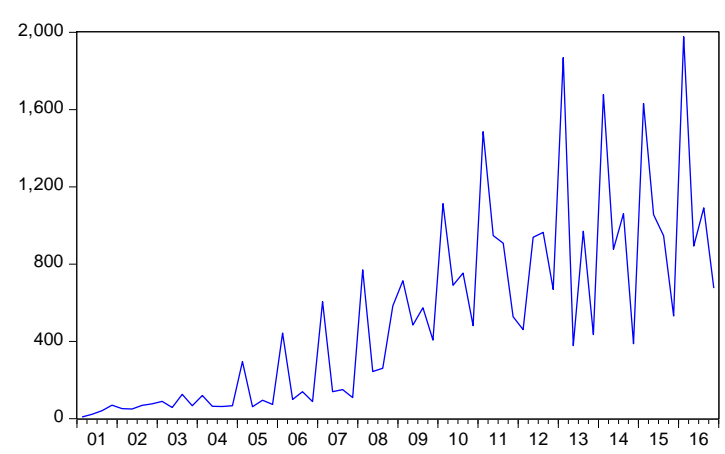

DIKGEL

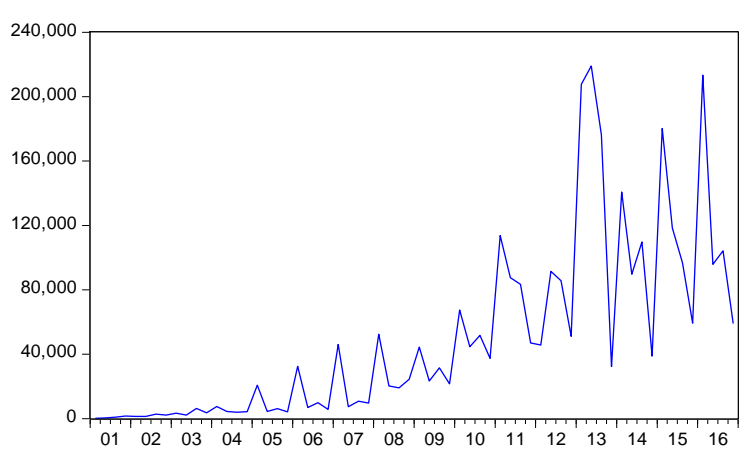

Şekil 2 2001-2016 yılları dikili satış miktarı ve gelirleri 
YAKSAT

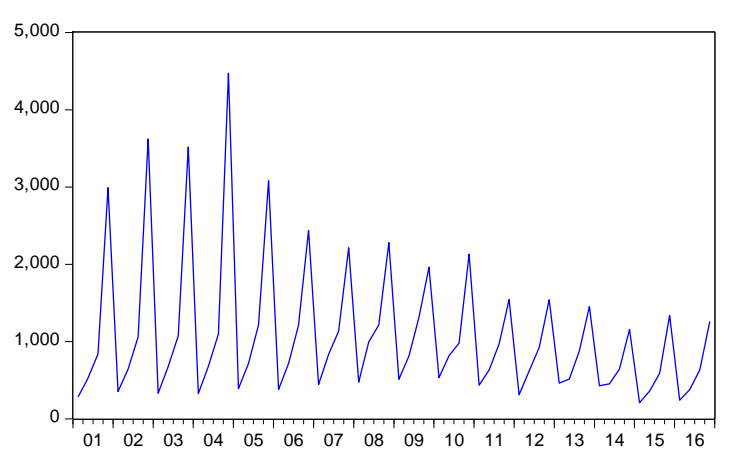

YAKGEL

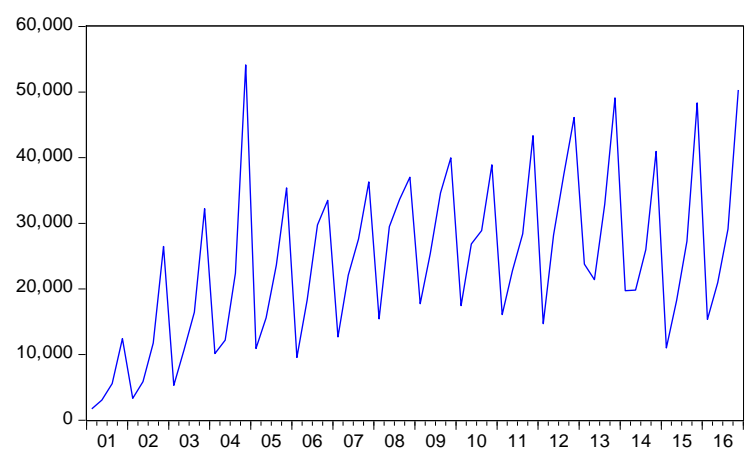

Şekil 3 2001-2016 yılları yakacak odun satış miktarı ve gelirleri

Ürün satış miktarları ve ürün gelirleri için oluşturulan 2001:Q1 - 2016:Q4 serilerinin ADF birim kök testleri yapılmıştır. Bu test için (3) nolu denklem, trend terimi dahil ve hariç olmak üzere ayrı ayrı tahmin edilmiştir. Denklemde bağımlı değişkenin kaç gecikmeli değerine yer verileceğine, maksimum gecikme uzunluğu 10 olmak üzere, Schwarz bilgi kriteri kullanılarak karar verilmiştir. ADF birim kök sonuçları Çizelge 2'de verilmiştir.

ENDSAT, ENDGEL, DIKSAT, DIKGEL, YAKSAT ve YAKGEL durağan değillerdir. Durağan olmayan zaman serilerinin durağan hale gelmesi için serilerin 1 . düzeyden farkları alınarak durağan hale getirilmişlerdir.
Çizelge 2 ADF birim kök sonuçları

\begin{tabular}{|c|c|c|c|}
\hline Değişkenler & Derece & $\begin{array}{l}\text { ADF } \\
\text { istatistiği }\end{array}$ & $t \quad P$ değeri \\
\hline \multirow[t]{2}{*}{ END $_{S A T}$} & Düzey & 3.265546 & 0.9996 \\
\hline & Birinci fark & -21.40206 & 0.0000 \\
\hline \multirow[t]{2}{*}{$\mathrm{END}_{\mathrm{GEL}}$} & Düzey & 4.986639 & 1.0000 \\
\hline & Birinci fark & -2.716801 & 0.0074 \\
\hline \multirow[t]{2}{*}{ DIK $_{\text {SAT }}$} & Düzey & 1.102122 & 0.9281 \\
\hline & Birinci fark & -13.10946 & 0.0000 \\
\hline \multirow[t]{2}{*}{ DIK $_{\mathrm{GEL}}$} & Düzey & 0.828361 & 0.8876 \\
\hline & Birinci fark & -5.535428 & 0.0000 \\
\hline \multirow[t]{2}{*}{ YAK $_{\text {SAT }}$} & Düzey & -1.001234 & 0.2080 \\
\hline & Birinci fark & -48.05888 & 0.0000 \\
\hline \multirow[t]{2}{*}{$Y_{A A K} K_{G L}$} & Düzey & 1.120618 & 0.9304 \\
\hline & Birinci fark & -25.83233 & 0.0000 \\
\hline
\end{tabular}
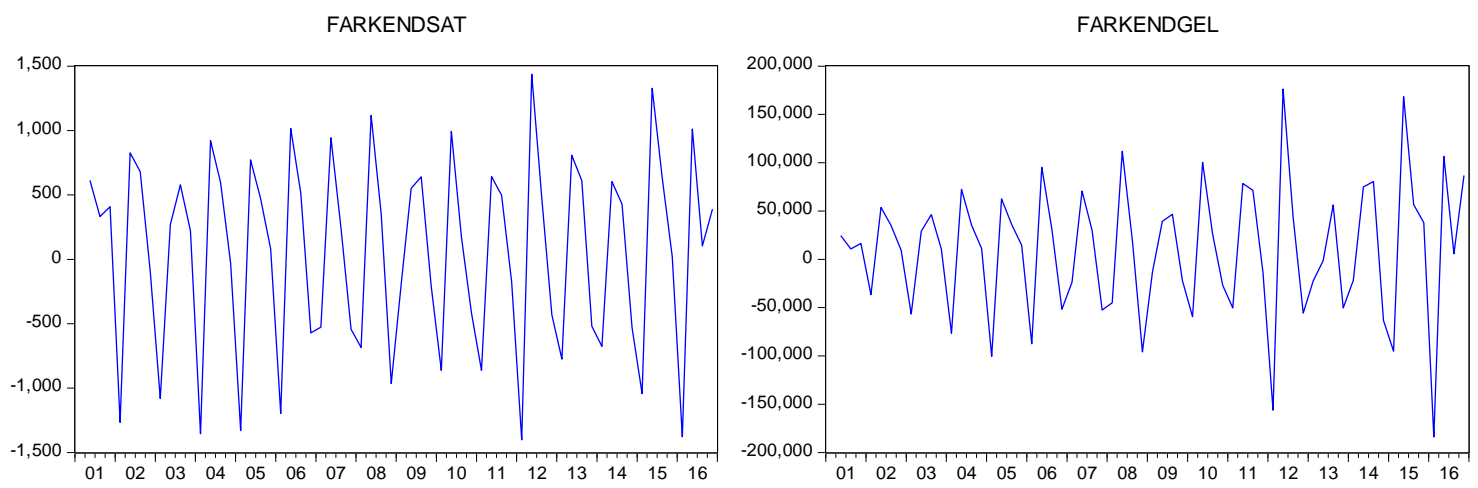

Şekil 4 I. dereceden farkı alınmış endüstriyel odun satış miktarı ve gelirleri

FARKDIKSAT

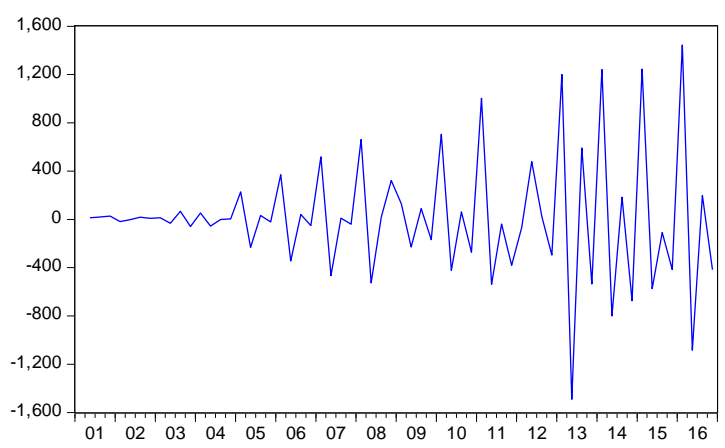

FARKDIKGEL

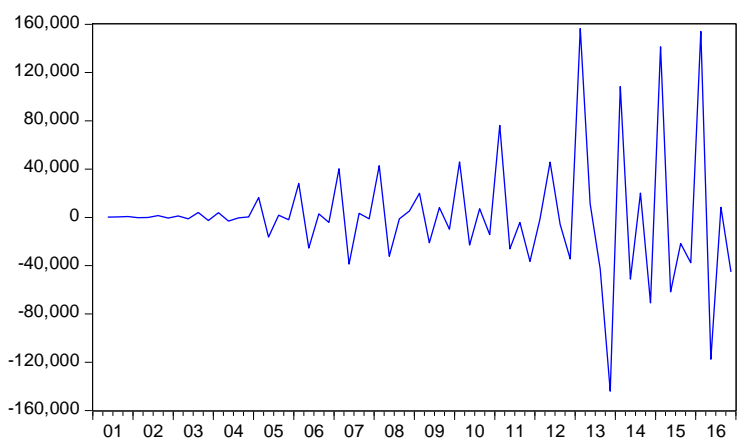

Şekil 5 I. dereceden farkı alınmış dikili satış miktarı ve gelirleri 
FARKYAKSAT

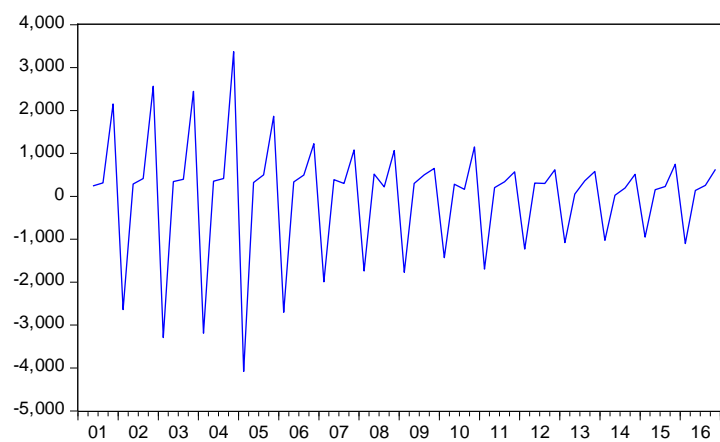

FARKYAKGEL

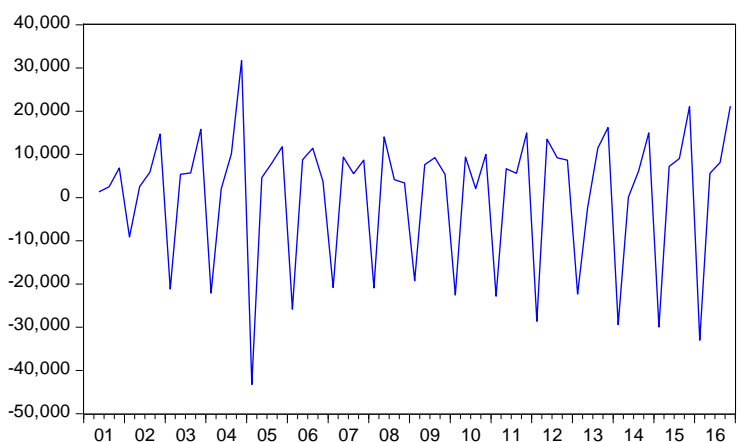

Şekil 6 I. dereceden farkı alınmış yakacak odun satış miktarı ve gelirleri

SAT ve GEL değişkenlerinin düzeyde durağan çıkması, bu seriler kullanılarak yapılacak regresyon analizlerinin düzmece olmayacağını göstermektedir. Bu seriler durağan olduğuna göre, yapılacak regresyon analizinin sonuçları da istatistiki açıdan gerçekçi olacaktır. Oluşturulan modellere ilişkin regresyon sonuçları Çizelge 3'te verilmiştir.

Çizelge 3 Regresyon sonuçları

\begin{tabular}{llllll}
\hline & END $_{\text {SAT }}$ & END $_{\mathrm{GEL}}$ & DIK $_{\mathrm{SAT}}$ & DIK $_{\mathrm{GEL}}$ & YAK $_{\mathrm{GEL}}$ \\
\hline$R^{2}$ & 0.81 & 0.93 & 0.41 & 0.68 & 0.65 \\
Sabit değer & 1472.004 & 30046.2 & 138.89 & 21323.22 & 1387.44 \\
YIl değişkeni & 28.96 & 7282.36 & 10.23 & 1342.32 & 12682.85 \\
\hline
\end{tabular}

Çizelge 4 2017:Q1 - 2027:Q4 yılları tahmini değerler

\begin{tabular}{|c|c|c|c|c|c|c|c|}
\hline \multirow[b]{2}{*}{ Yll } & \multirow[b]{2}{*}{ Çeyrek } & \multicolumn{2}{|l|}{ Endüstriyel Odun } & \multicolumn{2}{|l|}{ Dikili } & \multicolumn{2}{|l|}{ Yakacak Odun } \\
\hline & & $\begin{array}{c}\text { Satış Miktarı } \\
\left(.000 / \mathrm{m}^{3}\right)\end{array}$ & $\begin{array}{c}\text { Gelir } \\
(.000 / T L)\end{array}$ & $\begin{array}{c}\text { Satış Miktarı } \\
\left(.000 / \mathrm{m}^{3}\right)\end{array}$ & $\begin{array}{c}\text { Gelir } \\
(.000 / T L)\end{array}$ & $\begin{array}{c}\text { Satış Miktarı } \\
\text { (.000/ster) }\end{array}$ & $\begin{array}{c}\text { Gelir } \\
(.000 / T L)\end{array}$ \\
\hline \multirow[t]{4}{*}{2017} & 1 & 2316.35 & 415253.15 & 1402.59 & 191782.2 & 285.17 & 18418.98 \\
\hline & 2 & 3554.23 & 578720.62 & 682.782 & 102191.4 & 466.20 & 27597.05 \\
\hline & 3 & 4214.10 & 648802.23 & 832.1101 & 120392.4 & 703.70 & 38496.80 \\
\hline & 4 & 3852.67 & 578693.03 & 545.258 & 68100.24 & 1534.76 & 57793.58 \\
\hline \multirow[t]{4}{*}{2018} & 1 & 2396.34 & 439281.96 & 1473.992 & 201266.4 & 271.73 & 19118.41 \\
\hline & 2 & 3675.93 & 611731.01 & 717.1026 & 107183.4 & 443.97 & 28635.14 \\
\hline & 3 & 4357.16 & 685289.77 & 873.4178 & 126202.5 & 669.73 & 39931.41 \\
\hline & 4 & 3982.36 & 610786.53 & 571.9939 & 71347.5 & 1459.78 & 59927.42 \\
\hline \multirow[t]{4}{*}{2019} & 1 & 2476.34 & 463310.76 & 1545.392 & 210750.5 & 258.29 & 19817.84 \\
\hline & 2 & 3797.62 & 644741.40 & 751.4233 & 112175.3 & 421.73 & 29673.23 \\
\hline & 3 & 4500.22 & 721777.32 & 914.7255 & 132012.6 & 635.76 & 41366.02 \\
\hline & 4 & 4112.05 & 642880.03 & 598.7299 & 74594.84 & 1384.79 & 62061.26 \\
\hline \multirow[t]{4}{*}{2020} & 1 & 2556.33 & 487339.57 & 1616.792 & 220234.7 & 244.85 & 20517.27 \\
\hline & 2 & 3919.31 & 677751.78 & 785.744 & 117167.2 & 399.50 & 30711.33 \\
\hline & 3 & 4643.29 & 758264.86 & 956.0332 & 137822.6 & 601.80 & 42800.63 \\
\hline & 4 & 4241.74 & 674973.53 & 625.4658 & 77842.14 & 1309.81 & 64195.09 \\
\hline \multirow[t]{4}{*}{2021} & 1 & 2636.33 & 511368.38 & 1688.192 & 229718.8 & 231.41 & 21216.70 \\
\hline & 2 & 4041.01 & 710762.17 & 820.0647 & 122159.1 & 377.26 & 31749.42 \\
\hline & 3 & 4786.35 & 794752.41 & 997.3409 & 143632.7 & 567.83 & 44235.24 \\
\hline & 4 & 4371.43 & 707067.03 & 652.2018 & 81089.44 & 1234.82 & 66328.93 \\
\hline \multirow[t]{4}{*}{2022} & 1 & 2716.32 & 535397.19 & 1759.592 & 239203 & 217.97 & 21916.13 \\
\hline & 2 & 4162.70 & 743772.55 & 854.3854 & 127151.1 & 355.03 & 32787.52 \\
\hline & 3 & 4929.41 & 831239.96 & 1038.649 & 149442.8 & 533.86 & 45669.85 \\
\hline & 4 & 4501.13 & 739160.54 & 678.9377 & 84336.74 & 1159.83 & 68462.77 \\
\hline 2023 & 1 & 2796.31 & 559426.00 & 1830.992 & 248687.1 & 204.53 & 22615.56 \\
\hline
\end{tabular}

2017:Q1 - 2027:Q4 yılları için ENDSAT - ENDGEL, DIKSAT - DIKGEL ve YAKSAT - YAKGEL elde edilen tahmini değerler Çizelge 4'de verilmiştir. Elde edilen tahmin değerleri mevcut değerler ile çakıştırılarak Şekil 7-12 verilen grafikler oluşturulmuştur. 


\begin{tabular}{|c|c|c|c|c|c|c|c|}
\hline & 2 & 4284.39 & 776782.94 & 888.7061 & 132143 & 332.79 & 33825.61 \\
\hline & 3 & 5072.47 & 867727.50 & 1079.956 & 155252.9 & 499.90 & 47104.46 \\
\hline & 4 & 4630.82 & 771254.04 & 705.6737 & 87584.04 & 1084.85 & 70596.61 \\
\hline \multirow[t]{4}{*}{2024} & 1 & 2876.31 & 583454.80 & 1902.392 & 258171.3 & 191.09 & 23314.98 \\
\hline & 2 & 4406.09 & 809793.32 & 923.0267 & 137134.9 & 310.56 & 34863.71 \\
\hline & 3 & 5215.53 & 904215.05 & 1121.264 & 161062.9 & 465.93 & 48539.07 \\
\hline & 4 & 4760.51 & 803347.54 & 732.4096 & 90831.34 & 1009.86 & 72730.45 \\
\hline \multirow[t]{4}{*}{2025} & 1 & 2956.30 & 607483.61 & 1973.791 & 267655.4 & 177.65 & 24014.41 \\
\hline & 2 & 4527.78 & 842803.71 & 957.3474 & 142126.8 & 288.32 & 35901.80 \\
\hline & 3 & 5358.60 & 940702.59 & 1162.572 & 166873 & 431.96 & 49973.68 \\
\hline & 4 & 4890.20 & 835441.04 & 759.1456 & 94078.64 & 934.87 & 74864.28 \\
\hline \multirow[t]{4}{*}{2026} & 1 & 3036.30 & 631512.42 & 2045.191 & 277139.6 & 164.21 & 24713.84 \\
\hline & 2 & 4649.48 & 875814.09 & 991.6681 & 147118.8 & 266.09 & 36939.89 \\
\hline & 3 & 5501.66 & 977190.14 & 1203.879 & 172683.1 & 398.00 & 51408.29 \\
\hline & 4 & 5019.89 & 867534.54 & 785.8815 & 97325.94 & 859.89 & 76998.12 \\
\hline \multirow[t]{4}{*}{2027} & 1 & 3116.29 & 655541.23 & 2116.591 & 286623.8 & 150.77 & 25413.27 \\
\hline & 2 & 4771.17 & 908824.48 & 1025.989 & 152110.7 & 243.86 & 37977.99 \\
\hline & 3 & 5644.72 & 1013677.68 & 1245.187 & 178493.1 & 364.03 & 52842.90 \\
\hline & 4 & 5149.58 & 899628.04 & 812.6175 & 100573.2 & 784.90 & 79131.96 \\
\hline
\end{tabular}

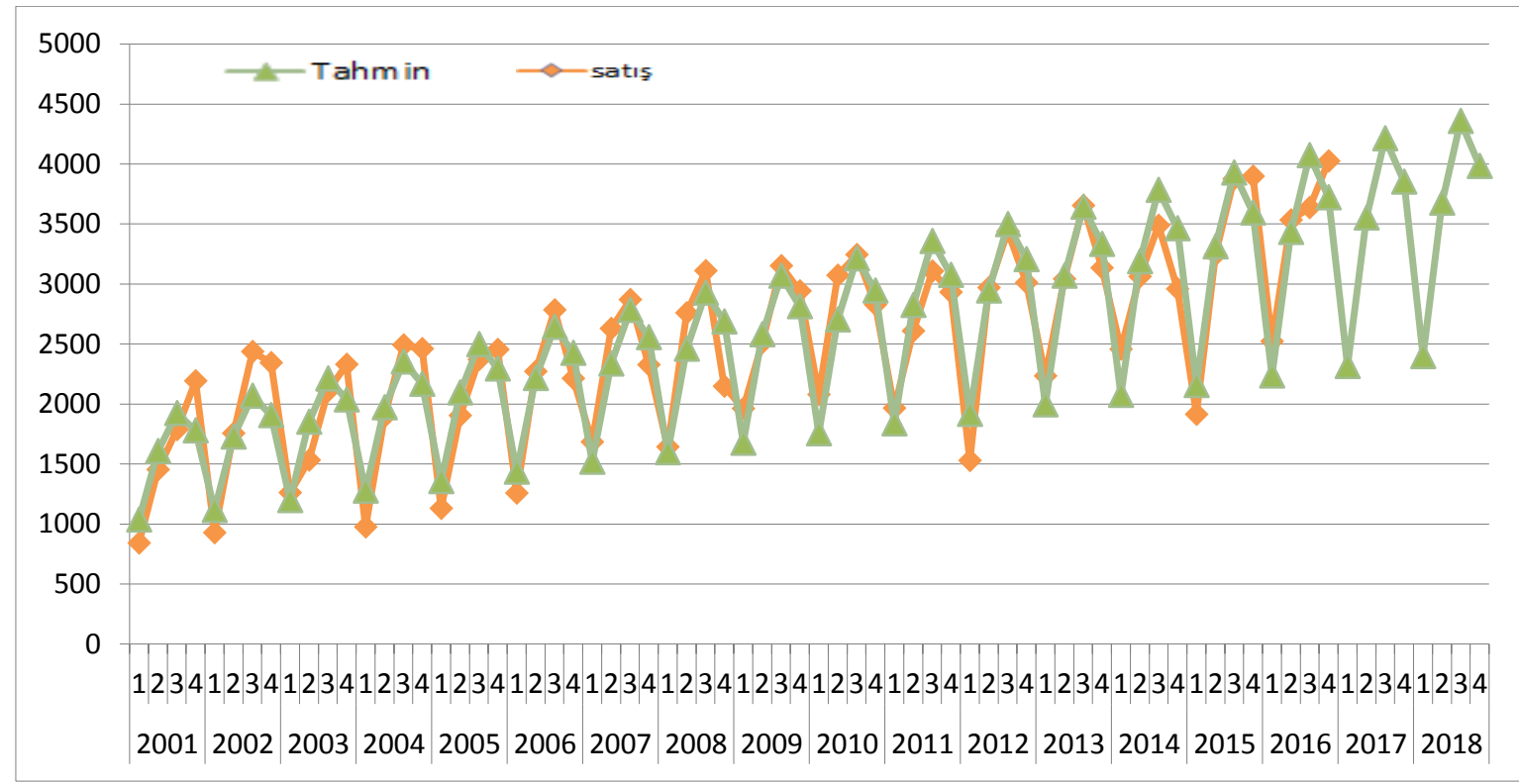

Şekil 7 Endüstriyel odun 2001 - 2016 mevcut satış miktarı ve 2017-2018 tahmini değerler

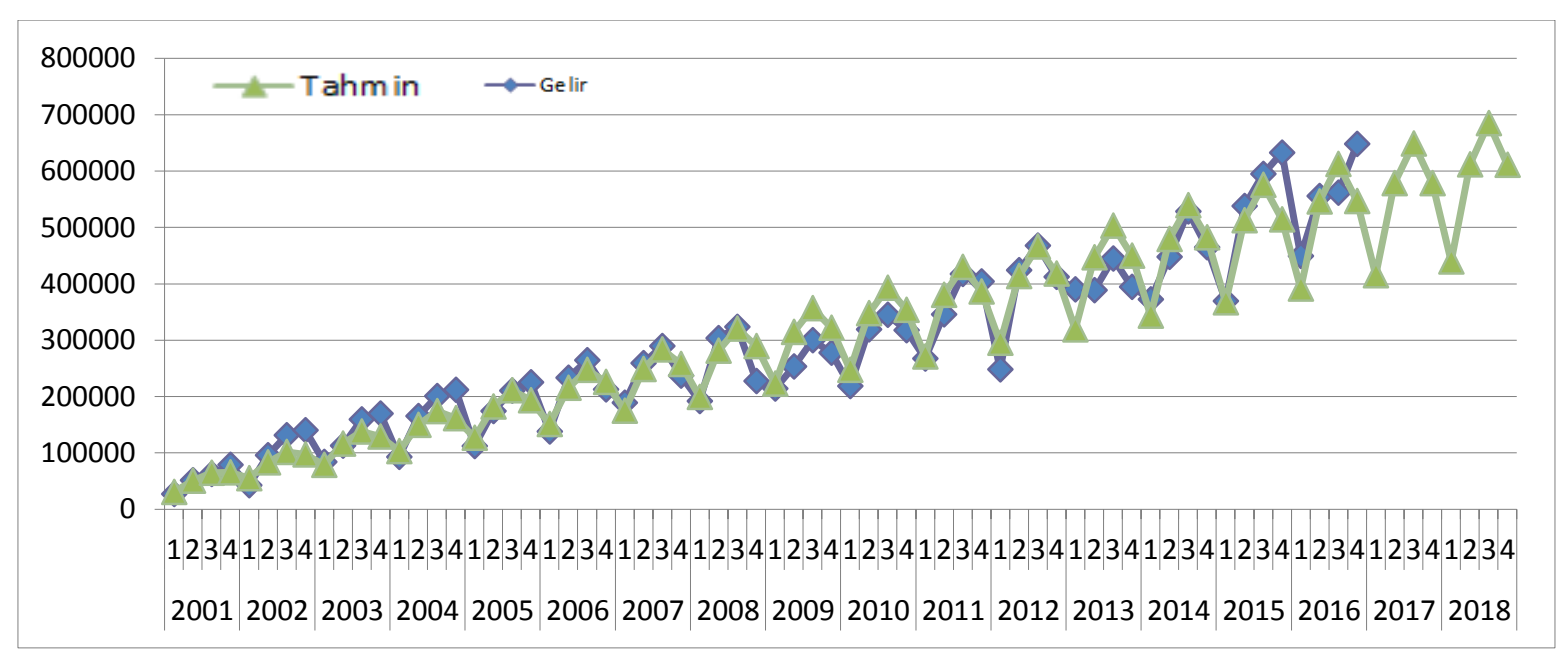

Şekil 8 Endüstriyel odun 2001 - 2016 mevcut gelir ve 2017-2018 tahmini gelir değerleri 


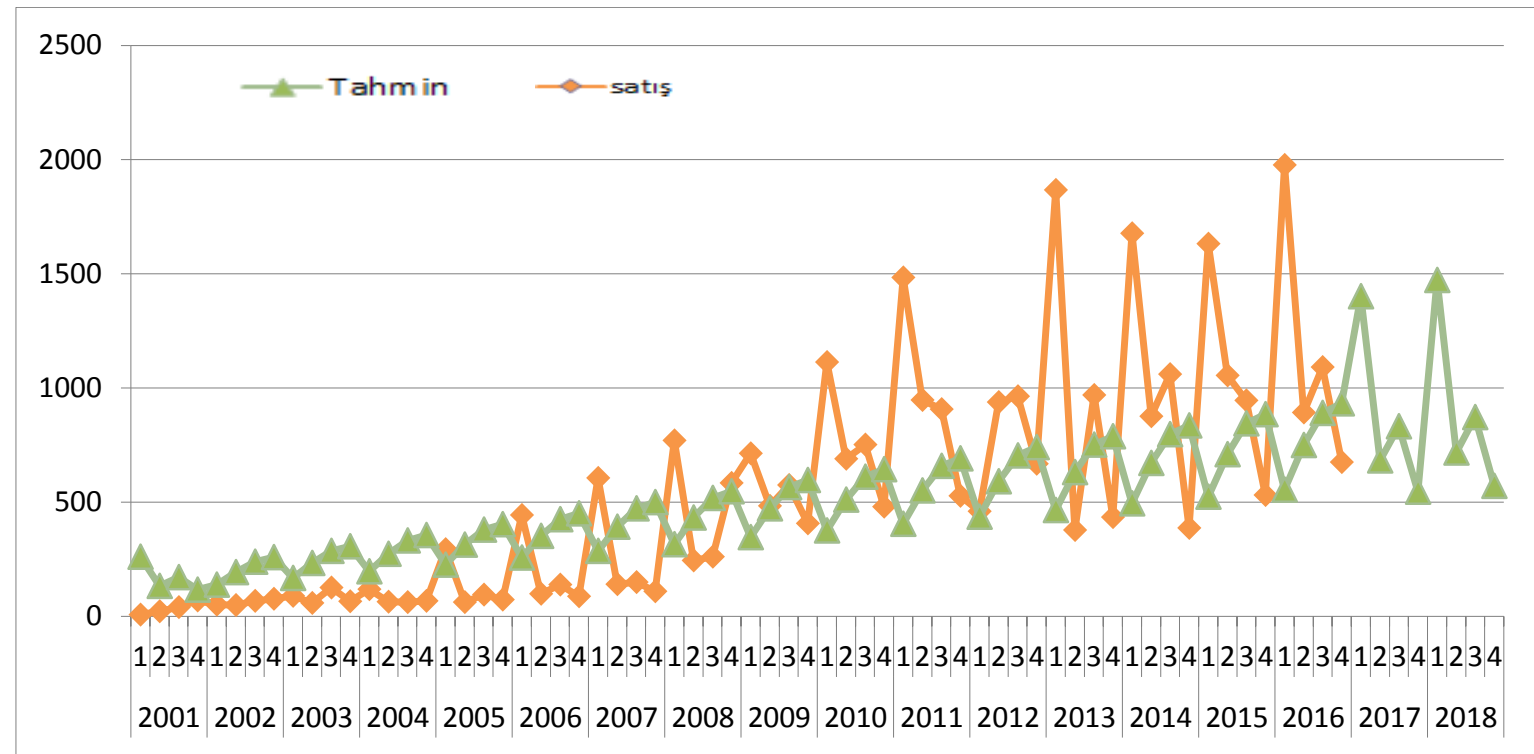

Şekil 9 Dikili 2001 - 2016 mevcut satış miktarı ve 2017-2018 tahmini değerler

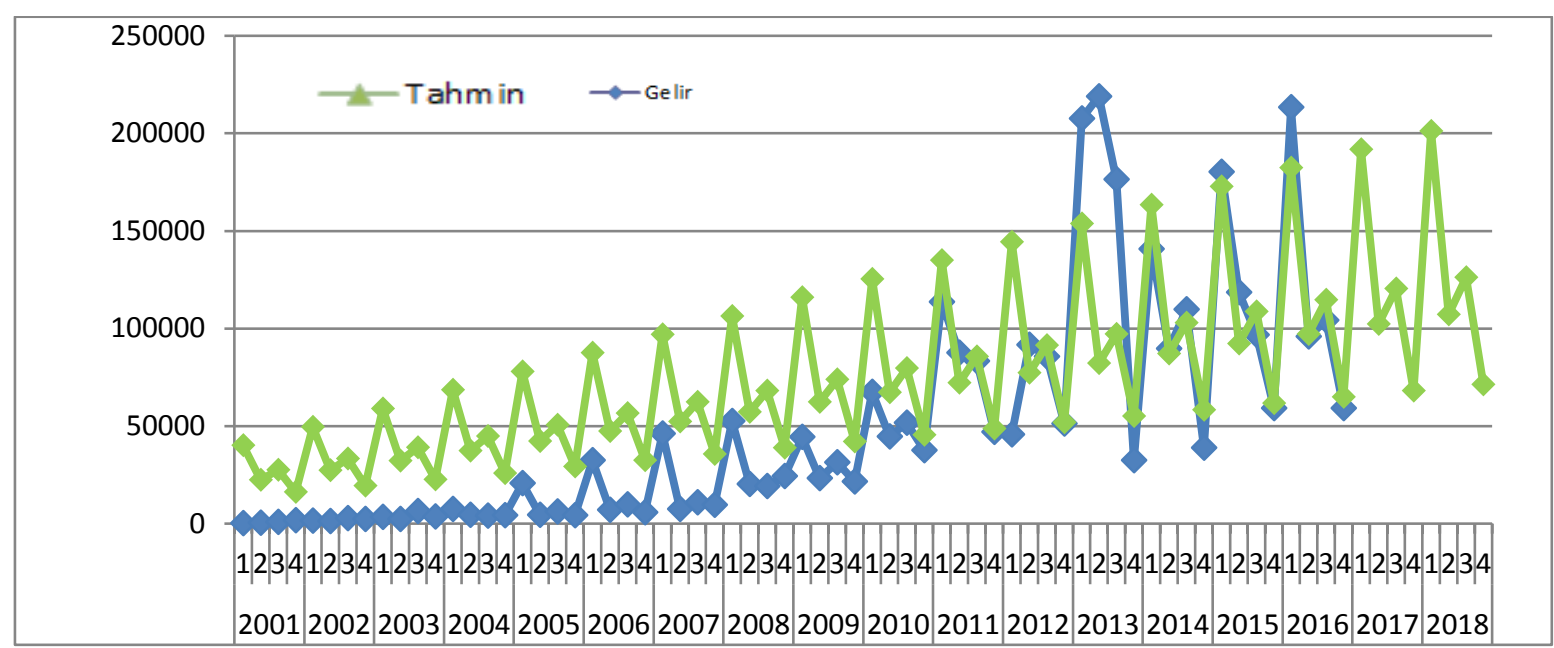

Şekil 10 Dikili 2001 - 2016 mevcut gelir ve 2017-2018 tahmini gelir değerleri

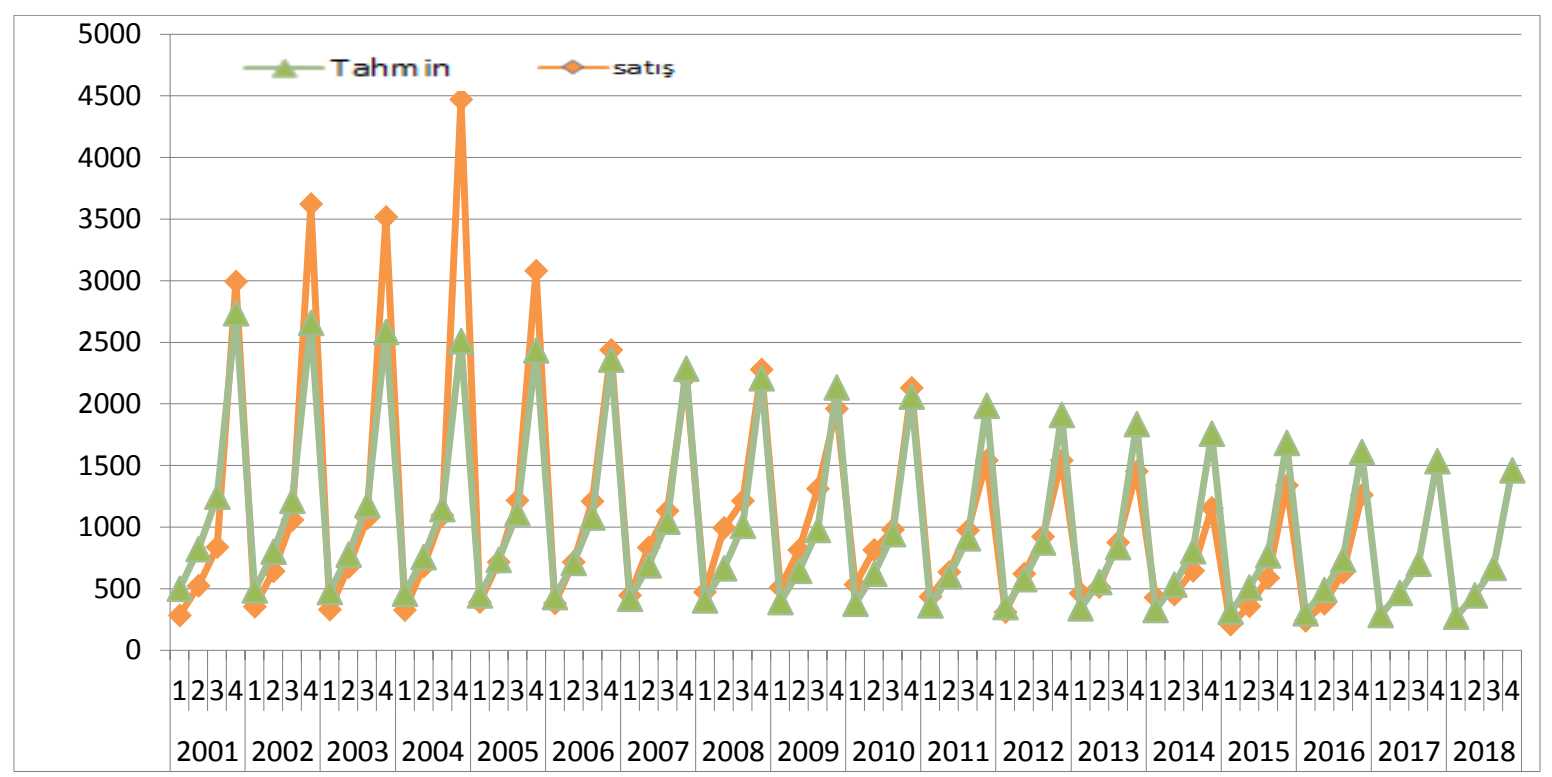

Şekil 11 Yakacak odun 2001 - 2016 mevcut satış miktarı ve 2017-2018 tahmini değerler 


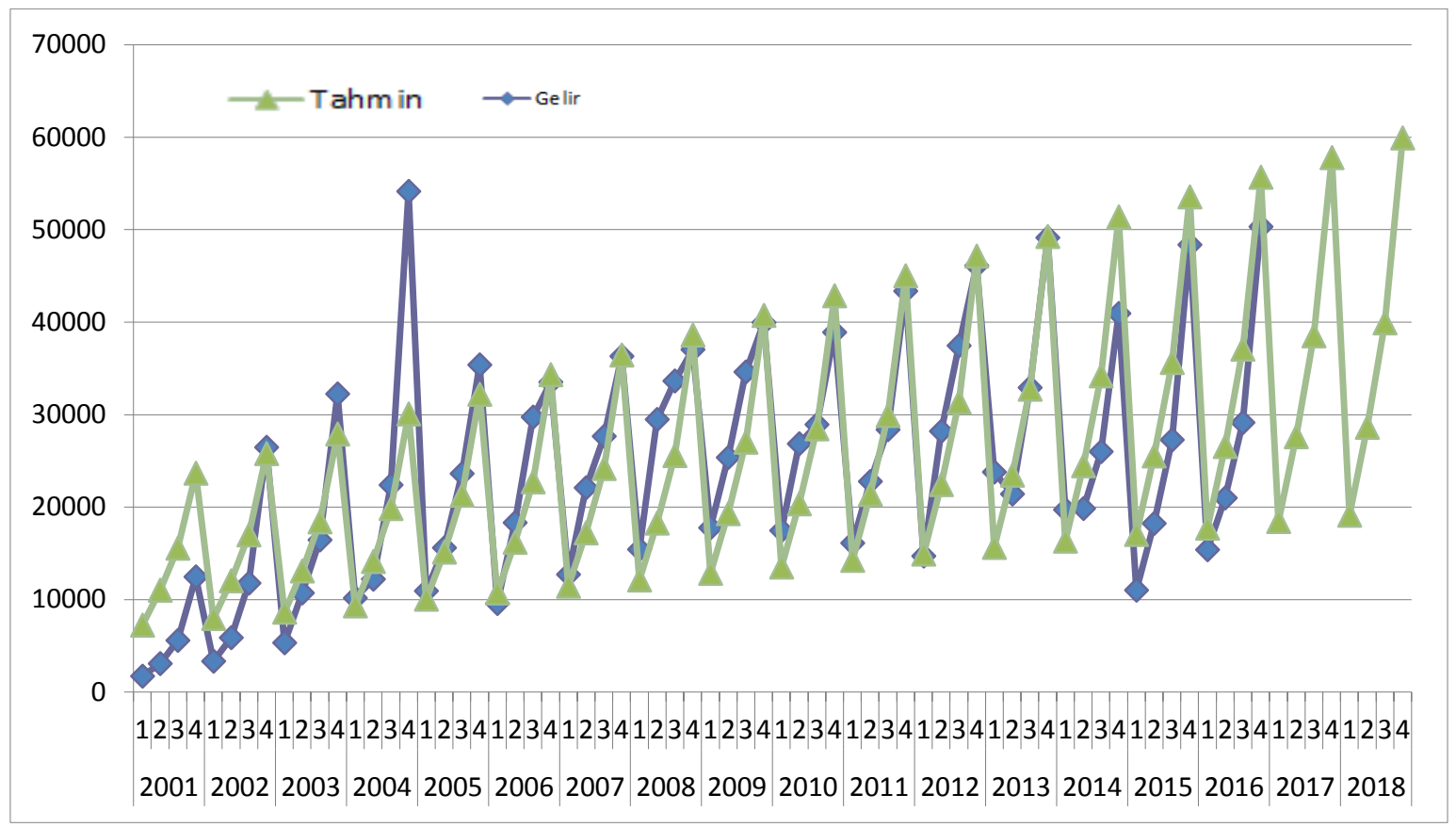

Şekil 12 Yakacak odun 2001 - 2016 mevcut satış miktarı ve 2017-2018 tahmini değerler

\section{TARTIŞMA VE SONUÇ}

Bu çalışmada OGM'nin 2001-2016 yılları endüstriyel odun, dikili ve yakacak odun satış miktarları ve gelirleri kullanılarak zaman serisi analiziyle 2017-2027 yıllarına ilişkin satış ve gelirlerine yönelik tahminler elde edilmiştir.

OGM'nin 2011-2016 yıllarına ilişkin veriler incelendiğinde endüstriyel odun satış ve gelir verilerinin oluşturulan modelle elde edilen tahmini değerlere yakın olduğu görülmektedir. Bu açıdan OGM, endüstriyel odun üretiminde değişen çevre ve pazar koşullarına göre üretim miktarı ve fiyatlandırmasını başarılıdır. Sadece 2001-2005 yılları arasında dünyada ve Türkiye' de yaşanan ekonomik krizin şatış miktarlarını üzerine etkili olduğu düşünülmektedir. OGM'nin 2027 yılı sonu ile endüstriyel odun satış miktarı ve gelirlerinde sırasıyla \%74.4 (Şekil 7) ve \%63.6'lık (Şekil 8) artış beklenmektedir. Benzer durum yakacak odun satış miktarları ve gelirlerinde görülmektedir. 2001-2005 yıllarında satış miktarları beklenenden yüksek gerçekleşmiştir. Ancak burada dikkat edilmesi gereken konu yakacak odun miktarının mevcut durumda ve gelecekte düşüş trendinde olmasıdır. Bu durumun nedeni olarak güneş sistemi, doğalgaz ve biyoenerji (odun peleti vb.) gibi oduna alternatif enerji kaynaklarının kullanımındaki artış düşünülmektedir. 2027 yılı sonu ile yakacak odun satış miktarında \%44.2'lik (Şekil 11) bir azalış beklenirken satışların aksine gelirlerinde \%57.6'lık (Şekil 12) artış beklenmektedir. Üretim maliyetleriyle birlikte mevsimsel odun fiyatlarında yaşanan artış, gelişen teknolojiyle birlikte her türlü odun ürününe talebin artması ve yakacak odunun enerji kaynağı olmasının yanında diğer enerji kaynaklarının (odun peleti, briket gibi) üretiminde de hammadde kaynağı olması gibi nedenlerden dolayı satış miktarlarında yaşanacak düşüşe rağmen yakacak odun gelirlerinde artış beklenmektedir. Üzerinde durulması gereken önemli bir konu dikili satışlardır. Dikili satışlar 2016 yıl sonu OGM'nin odun ürünleri satış miktarı ve gelirleri içinde sırasıyla \%23 ve $\% 16.8^{\prime}$ dir. Ancak mevcut değerler (Şekil 9) ve geleceğe yönelik tahminler (Şekil 10) incelendiğinde satış ve gelirlerin beklenenden oldukça düşük gerçekleştiği görülmektedir. Çalışma kapsamında dikili satış usul ve esaslarına yönelik bir sonuca varılması ve bu yönde önerilerin geliştirilmesi mümkün değildir. Bu nedenle bu durumun daha detaylı bir şekilde incelenmesi ve farklı çalışmalarla ortaya konulması gerekmektedir.

Türkiye'de Orman ve Su İşleri Bakanlığı'nda Meteoroloji Genel Müdürlüğü'nün hidrolojik sistemlerin modellenmesi (MGM 2017) dışında zaman serisini kullanımı yoktur. Orman varlığının değişimi (Sarıyılmaz ve 
Musaoğlu 2014) ve odun ürünleri üzerine zaman serileri analizi yönteminin kullanıldığı (Öztürk ve ark. 2011; Kayacan ve ark. 2012a; 2012b; 2013) çalışmalar bulunmasına rağmen çalışma sayısı yeterli düzeyde değildir. Sahip olunan kaynakların daha etkin ve verimli kullanılabilmesi bu çalışmaların sayısının da artması gerekmektedir.

\section{KAYNAKLAR}

Allen RGD (1964) Statics for economists. Mc-Millan, UK.

Beşkaya A ve Manan Ö (2009) Ekonomik özgürlükler ve demokrasi ile ekonomik performans arasındaki ilişkinin zaman serileri ile analizi: Türkiye örneği. ZKÜ Sosyal Bilimler Dergisi 5:47-66.

Enders W (2014) Applied econometric time series. Wiley, Chichester.

Kayacan B, Ucal MS, Ozturk A, Bali R, Kocer S, Kaplan E (2012a). Modeling and forecasting the demand for industrial roundwood in Turkey: A primary econometric approach. Journal Of Food Agriculture \& Environment 10: 1127-1132.

Kayacan B, Ucal MS, Ozturk A, Bali R, Kocer S, Kaplan E (2012b) A primary econometric approach to modeling and forecasting the demand for fuelwood in Turkey. Journal Of Food Agriculture \& Environment 10: 934-937.

Kayacan B, Kara O, Ucal MS, Ozturk A, Bali R, Kocer S, et al. (2013) An econometric analysis of imported timber demand in Turkey. Journal Of Food Agriculture \& Environment 11:791-794.

Langford D and Male S (2001) Strategic management in construction, Blackwell Science Ltd., USA.

MGM (Meteoroloji Genel Müdürlüğü) 2017 Hidrolojik sistemlerin modellenmesi, Zaman serisi ve mekânsal analiz. https://www.mgm.gov.tr/genel/hidrolojikmodelleme.aspx?s=3. Erişim tarihi: 13 Haziran 2017

Nut PC and Backoff RW (1992) Strategic management of public and third sector organisations: A handbook for leaders. Jossey-Bass, San Fransisco.

Özturk A, Kayacan B, Dikilitas K (2011) A linear price model for insectdamaged industrial roundwood: A case study in northeastern Turkey. African Journal Of Business Management 5:8552-8557.

Pamuk G, Erkut H ve Ülegin F (1997) Stratejik yönetim ve senaryo tekniği. İrfan Yayıncılık, İstanbul

Sarıyılmaz FB ve Musaoğlu N (2014) Zaman serilerinin değişim analizlerinde kullanımı: İstanbul Sarıyer örneği, UZAL-CBS 2014, istanbul.

Tarı R (2014) Ekonometri. Umuttepe Yayınları, Kocaeli.

Zeren F (2010) Mekansal etkileşim analizi. Ekonometri ve İstatistik 12:18-39. 